\title{
Starving Ireland, Hungry Australia: The Irish Female Orphan Emigration Scheme, 1848-1850
}

Emily Lieffers

\begin{abstract}
:
From 1848-50, the British government sent 4,175 famine-stricken orphan girls from Ireland to Australia to give them a better life and fulfill population needs in the colony. The controversy surrounding the orphan emigration scheme suggests that prejudices against the Irish and their poverty were easily exported to a colonial setting. The girls' physical appearance and ignorance, largely a result of poverty and terrible conditions in workhouses, were taken as racial deficiencies, while their religion was viewed as a threat. This orphan scheme is thus a valuable case study for historians seeking to explore the limits of colonial citizenship in the British Empire and to reinvigorate historiography concerning Anglo-Irish relations in the Famine era.
\end{abstract}

From 1848-50, the British government embarked on a scheme to send famine-stricken orphan girls from Ireland to Australia to give them a better life and fulfill population needs in the colony. Though small in scope compared to large-scale emigration to North America during the Famine years, the Irish orphan scheme is a valuable case study for historians and illuminates the relationship between Ireland and colonial Britain. Historians are well-acquainted with prejudices against the Irish but less attention has been given to these stigmas in a Pacific colonial setting. The controversy surrounding the orphans in the scheme suggests that prejudices against the Irish and their poverty were easily exported to a colonial setting. With some exceptions, Irish girls were exposed to consistent discrimination from 
Australians as well as colonial officials, who largely concurred that the orphans were second-rate compared to English or Scottish girls. The girls' poverty and ignorance resulting from their time in Irish workhouses were used as weapons against them, suggesting that prejudices applied not only to Irish men but to vulnerable children as well. In the early stages of the scheme, a hungry labour market ensured the orphans employment. Over time, and with a reduced labour shortage, however, deep-seated intolerance of the Irish led to a chorus of complaints and the eventual end of the short-lived scheme. Through a comparative discussion of the situations in Ireland and Australia, followed by an analysis of the scheme itself, this paper will show that anti-Irish prejudices were often transported around the world, despite the British Empire's rhetoric of inclusion in the colonial project.

\section{Starving Ireland, Hungry Australia}

During the period leading up to the Famine, the situation for destitute Irish children was precarious. The closure of foundling hospitals and withdrawal of government assistance left no public institutions to provide for charity children; most children were either taken in by friends or relatives, or resorted to begging, a situation which emphasised the "crying need for the introduction 
of a national poor law system." In September 1833 the British government established a commission to enquire into the measures needed to provide for Ireland's poor. The commission sat for three years, gathering evidence from across the country, ${ }^{2}$ and reported in 1836 that there were over 2,385,000 people who were destitute for over thirty weeks a year in Ireland. ${ }^{3}$ It concluded that an English workhouse system was not suitable for Ireland because the system was aimed to compel people to work; in Ireland, however, there were no jobs. The commission encouraged the support of private charities, public works projects, and emigration to help destitute workers and children find fortune elsewhere. ${ }^{4}$ As historian Joseph Robins points out, the "commission's proposals were generally enlightened and not hampered by currently held economic doctrines; not surprisingly, they were distasteful to the government."

The British government rejected the commission's views and sent George Nicholls, a Poor Law commissioner, to examine whether the English Poor Law could be applied to Ireland. ${ }^{6}$ After Nicholls' six week tour of the country,

'Joseph Robins, The Lost Children: A Study of Charity Children in Ireland, I 700-1900 (Dublin: Institute of Public Administration, 1980), I48.

2 George Nicholls, A History of the Irish Poor Law, in Connexion with the Condition of the People, 1856 (Reprint, New York: Augustus M. Kelley, 1967), II 8.

${ }^{3}$ Robins, 157.

4 Ibid.

5 lbid., 158.

6Nicholls, 129-30. 
the English workhouse system, with some modifications, was applied to Ireland in the Irish Poor Relief Act in July 1838.' Though local Poor Law Committees were now entitled to borrow money to fund emigration, this option was rarely used until the late $1840 s,{ }^{8}$ and instead, relief was only available in workhouses of a repellent and penal nature. ${ }^{9}$ The government provided no funding for orphans outside of the workhouse and made no effort to create a familial environment for destitute children. Though Nicholls recommended that some authority could be given to apprentice workhouse children, he stressed that the Poor Law should "not [place] the children in better circumstances than the children of independent labourers."10 The Poor Law thus made no distinction between various destitute peoples; all could either come to the workhouse, or survive by begging. Nicholls was aware of the Poor Law's weaknesses and its inability to handle more than 100,000 people at once; however, he believed the law would suffice because a general famine was unlikely. ${ }^{11}$

The spread of the Famine from 1845 onwards made the situation for destitute peoples and children especially dire. In the early stages of the Famine, the workhouses remained unfilled due to public distrust of the system; in

\footnotetext{
7 Robins, 159-60.

8 Donald MacKay, Flight from Famine: The Coming of the Irish to Canada (Toronto: Dundurn Press, 2009), 192.

9 Robins, 158.

10 lbid., 159.

11 Mackay, I9I.
} 
March 1846, only 51,000 people lived in workhouses. ${ }^{12}$ By 1847, however, the average daily occupation of workhouses was 83,283; in 1848 this grew to 128,020 , in 1849 193,650, and in 1850 211,047.. ${ }^{13}$ Children usually occupied about half of the workhouse population; in $1844,22,585$ children were provided for, increasing to 25,196 in 1846. By June 1849 90,289 children lived under this system. ${ }^{14}$ The lack of outdoor relief until the 1847 Poor Relief Extension Act (Soup Kitchen Act) meant that many pauper families could not afford to take in orphaned relatives or neighbours. ${ }^{15}$ Most children living in workhouses were orphaned by famine conditions, but a large number were abandoned by their parents, often with the expectation of future reunion. ${ }^{16}$ A Poor Law inspector in 1847, however, stated that the children in workhouses "were in worse condition than those of families who had chosen to starve in their own homes."17 A contemporary commented that the provision for workhouse children was "in the main efficient and satisfactory, although conducted at first in a spirit of perhaps too great economy." ${ }^{18}$ This was an understatement. Children were neglected in the system, surrounded by disease and death and scarred by their

\footnotetext{
12 Robins, 168-69.

13 Ibid., 170.

14 lbid., 179.

15 Ibid., 172.

16 Gerard Moran, Sending out Ireland's Poor: Assisted emigration to North America in the nineteenth century (Dublin: Four Courts Press, 2004), 129.

17 Robins, 189.

18 “Irish Poor Law: past, present and future" (London: James Ridgway, 1849), 3-4.
} 
horrific plight. Though children were supposedly given three hours of instruction a day in religion, reading, and arithmetic to "train them in habits of usefulness, industry and virtue,"19 in reality little training was given and children were raised in ignorance. As Robins notes, a stigma of the workhouse pauper and child emerged, a disgrace that would follow some inmates throughout their life and around the world. ${ }^{20}$

While the number of destitute children in Ireland drained public funds and strained an inadequate system, Australia suffered from the opposite problem: a labour shortage. In August 1838 the House of Commons announced the imminent end of convict transportation to eastern Australia, ${ }^{21}$ leaving colonists confronted with the question of labour. Consideration was given to introducing indentured labour from China and India, but colonial authorities quickly halted the scheme; it was European, especially English, workers who were wanted. ${ }^{22}$ Transforming the colony from "a stagnant English prison" into an attractive immigrant location, however, was a gradual and difficult process. ${ }^{23}$ Colonial authorities

19 "Second Annual Report, Irish Poor Law Commissioners," House of Commons Papers, 1849 (II I8), xxv, quoted in Robins, 177.

20 Robins, 74.

21 Campbell, Ireland's New Worlds: Immigrants, Politics, and Society in the United States and Australia, 1815-1922 (Madison, WI: University of Wisconsin Press, 2008), I5. 22 Malcolm Campbell, Ireland's New Worlds: Immigrants, Politics, and Society in the United States and Australia, 1815-1922 (Madison, WI: University of Wisconsin Press, 2008), 15.

23 Patrick O'Farrell, The Irish in Australia: I 788 to the Present (Sydney, University of New South Wales Press, 2000), 9. 
circulated emigrant guides, pamphlets and testimonials among Britain and Ireland's working classes, stating that Australia would provide a better diet and independence for those willing to work. $^{24}$ Improving Australia's reputation also required a "demonstration of the improving moral tone." 25 In particular, Australia needed women to tame the frontier, be domestic servants, and civilize its male population, which outnumbered its female population by a ratio of 17 to 1 in some areas. ${ }^{26}$ The first parties of women in Australia, many Irish, were convicts and carried a significant stigma of immorality with them. ${ }^{27}$ Contemporary Irish women living in the colony struggled to shed this disgrace in a society which continued to disproportionately emphasize the nature and number of "fallen" convict women in their society. ${ }^{28}$ Indeed, the House of Commons stated that Australian society was "unique" in its degradation, "a peasantry without domestic feelings of affections, without parents or relations, without wives, children, or homes." 29 The presence of interbreeding with Aborigine women and the supposed degeneration of the white race were also seen as symptoms of low morality, which only "a plentiful

\footnotetext{
24 Campbell, 15.

25 Ibid., 16.

26 Ibid.

27 Portia Robinson, The Hatch and Brood of Time: A study of the first generation of native-born white Australians, I 788-I828, Vol. I (Oxford: Oxford University Press, 1985), 84.

28 lbid., 68.

29 House of Commons, Select Committee on Transportation, Report, I838, xxx$x x x i$, quoted in Campbell, 16.
} 
supply of white women," with strong morals, could solve. ${ }^{30}$

Several realities in Australia made attracting such women difficult and enhanced the appeal of assisted emigration of Irish orphan girls. The cost of passage proved a major barrier: a passage to Australia at this time cost five times that to the United States or British North America, making emigration to the colony unthinkable for most labourers or cash-strapped workhouses. ${ }^{31}$ The willingness of Australian authorities to pay for transportation of women thus made the scheme much more attractive. It also remained difficult to attract workers, especially single women of "good character," who would willingly leave Britain for distant, untamed Australia with little chance of return. Assisted emigration schemes for women and girls from Britain and Ireland struggled to meet their quotas and resorted to "sweeping the streets" for willing candidates. ${ }^{32}$ A scheme in 1831 saw the assisted emigration of fifty-nine girls from the Cork Foundling Hospital to New South Wales. The colonial government, however, made little provision for the protection of the girls during the journey and in the colony itself; many of the girls had "consorted promiscuously" with sailors on the journey and became

\footnotetext{
30 Joseph A. Robins, “Irish Orphan Emigration to Australia, 1848-1850," Studies: An Irish Quarterly Review, Vol. 57, No. 228 (1968): 373.

31 Campbell, 16.

32 O'Farrell, 72.
} 
prostitutes upon arrival. ${ }^{33}$ By 1838 , there were apparently six hundred homeless girls, mostly Irish, wandering the streets of Sydney. ${ }^{34}$ The Australian public was disappointed by the incompetence of Irish migrants and resented "that public money should be spent on what were judged poor returns and to help Britain to ... rid itself of its troublesome Irish." 35 Australian authorities were emphatic that the next group of assisted emigrants be of suitable character.

\section{The Scheme (1848-50)}

The Irish orphan emigration scheme emerged out of an intersection of British and Australian demands. The British authorities saw that the number of destitute Irish children in workhouses was a serious social problem and a drain on their financial resources, while colonial Australians voiced their support for assisted emigration. C. A. Fitzroy, the New South Wales governor, was under extreme pressure from colonists to secure labour and improve gender parity. ${ }^{36}$ In 1847, the Speaker of the New South Wales legislature wrote Lord Monteagle, an Irish peer, saying "We wish to receive emigrants; we are willing to pay for them. There are millions among you dying of hunger; let us have those starving crowds; here they will find a superabundance of the necessaries of

\footnotetext{
33 Robins, "Irish Orphan Emigration to Australia," 372.

34 Ibid., 373.

35 O'Farrell, 73.

36 Robins, The Lost Children, 200.
} 
life." ${ }^{37}$ South Australia also cautiously voiced support for the scheme. ${ }^{38}$ The colonial and home secretaries, Sir Earl Grey and Sir George Grey respectively, voiced their approval, and in February 1848, the government announced its participation in a scheme to send female workhouse orphans over age fifteen to Australia. ${ }^{39}$

The proposal aimed to solve colonial and local problems at once, and child migration was seen to have several advantages. Firstly, it was cheaper for local authorities to pay a one-off sum for the emigration of their charges than to be burdened with the cost of long-term inmates. ${ }^{40}$ Secondly, children could be moulded into good colonial citizens and posed less threat of colonial unrest. Indeed, Australian Captain Stanley Carr is recorded in the Hansard as having said "the emigration of pauper children is preferable to that of adults," ${ }^{11}$ while Lieutenant Carew noted that "they have the advantage of youth, and will therefore be much sooner moulded to the habits and customs of that colony." 42 As historical geographer Patrick Duffy points out, planned migration

37 Second Report of Select Committee of Irish Poor Laws, April I849, p.464, House of Commons Papers 1849 (228), xvi, quoted in Robins, The Lost Children, 200.

38 Robins, The Lost Children, 202.

39 Moran, 130.

40 Philip Bean, and Joy Melville, Lost Children of the Empire: The Untold Story of Britain's Child Migrants (London: Unwin Hyman Limited, 1989), 34.

4I Stanley Carr, Hansard, quoted in Bean and Melville, 33.

42 Lieutenant Carew, R.N. Letter to the Right Honourable Earl Grey, Secretary of State, 5 August 1848, in Irish University Press Series of British Parliamentary Papers: Correspondence and Papers Relating to Emigration and Other Affairs in Australia, 184950, Vol. II (Shannon: Irish University Press, 1968-9), 352. 
would hopefully "bring about outcomes deemed desirable by the controlling agency," and Irish girls could be made loyal colonial citizens. ${ }^{43}$ Earl Grey and Treasury official Charles Trevelyan also approved of the proposal because the Australian authorities were prepared to pay for transportation. ${ }^{44}$ In its early stages, British officials thus viewed the scheme optimistically.

The scheme was met with mixed reaction in Ireland, however. Though there is little information concerning the sentiments of the orphans themselves, hard-pressed poor unions viewed the proposal as a blessing. By May 1848, 86 unions had provided the Emigration Commissioners with lists of suitable candidates. Indeed, most unions were so enthusiastic about the scheme that the demand exceeded the number of available spaces. ${ }^{45}$ Many Irish nationalists, on the other hand, voiced their opposition and saw emigration as "the consummate evil, draining the nation's life-blood." ${ }^{6}$ The Nation, the mouthpiece for the Young Ireland movement, described the scheme as "one of the most diabolical proposals ever made or conceived since Cromwell's time," while The Tipperary Vindicator called the proposal a form of white slave traffic. $^{47}$ Furthermore, a member of the

\footnotetext{
43 Patrick J. Duffy, Introduction to To and from Ireland: Planned Migration Schemes C. 1600-2000, ed. Patrick J. Duffy (Dublin: Geography Publications, 2004), 3.

44 Campbell, 85.

45 Moran, 130.

46 O'Farrell, 54.

47 The Nation, 26 February 1848, 137; The Tipperary Vindicator, 3 January 1849, 2, quoted in Robins, "Irish Orphan Emigration to Australia," 375.
} 
Roscrea Board of Guardians resigned in response to Poor Law policies, including the fact that pure Irish girls were being sent to become the wives and mistresses of "bushmen or savages." 48 The scale of human misery in Ireland at this time, however, was such that the scheme went largely unnoticed by most of the population. ${ }^{49}$ Historian Patrick O'Farrell notes that "[t]he very fact that emigration was seen by the British as a cure for Ireland's ills, and by Irish nationalists as a disaster, induced something akin to penitence in many, certainly confusion." ${ }^{50}$ Ambiguities surrounding the scheme suggest a complex emotional connection to the greater Famine diaspora and the sense of failure, dispossession and hope that surrounded such large-scale migration.

Poor Law and Australian authorities were keen to avoid the mistakes of previous emigration attempts and thus planned the scheme with great meticulousness. Organizers wanted only the right sort of girl to immigrate, and asked colonial governors to secure employment for them with respectable employers. ${ }^{51}$ Colonial authorities made it clear that "this particular scheme would require close moral and religious superintendence" 52 and that they wanted only "those whose education and moral and religious training afford

48 The Tipperary Vindicator, 24 January I849, 2, quoted in Robins, "Irish Orphan Emigration to Australia," 376.

49 Robins, "Irish Orphan Emigration to Australia," 376.

50 O’Farrell, 62.

51 Robins, "Irish Orphan Emigration to Australia," 374.

$52 \mathrm{lbid}$. 
a reasonable guarantee that they will become active and useful members of a society which is in a state of healthy progress." 53 Emigration Commissioners had their agent in Dublin examine the girls and receive character testimonials from workhouse authorities. ${ }^{54}$ The journey itself was also well-provisioned. Girls were given new clothing, Bibles and prayer books according to their denomination, and a wooden box to hold their items. ${ }^{55}$ Furthermore, a surgeon-superintendent, a matron, submatrons, and, if possible, a religious instructor, were appointed to each ship, and the girls were separated from other emigrants. ${ }^{56}$ Indeed, Australian immigration was "ordered, organised and protected in a way American immigration was not"; the conscience and pride of English politicians and administrators were at stake, and migration was seen as "an imperial transaction to be conducted at the highest standards." 57 Colonial officials viewed the situation as particularly delicate, and C. J. Bailey apparently told Lord Monteagle in October 1848 "we must be careful not to plant a New Ireland in any colony." 58 The Irish, whether by their choice or not

53 "Emigration Commission Report," quoted in Robins, The Lost Children, 201. 54 Lieutenant Henry, R.N., Emigration Officer, Letter to Colonial Land and Emigration Office, 30 May, 1849, in Irish University Press Series of British Parliamentary Papers: Correspondence and Papers Relating to Emigration and Other Affairs in Australia, 1849-50. Vol. II (Shannon: Irish University Press, 1968-9), 5 I 2.

55 Robins, The Lost Children, 204.

56 Robins, "Irish Orphan Emigration to Australia," 377.

57 O’Farrell, 65.

58 C. J. Bailey, October 1848, quoted in O'Farrell, 65. 
and whatever apprehensions the British may have had, were now complicit in the imperial project. ${ }^{59}$

The scheme was immediately surrounded by a level of controversy, however, that suggested that a colonial setting would not remove many ingrained prejudices against the Irish. In June 1848, the Earl Grey, the first orphan ship, left Plymouth for Sydney with 185 girls, followed by the Roman Emperor in July, destined for Adelaide. $^{60}$ Even before docking in Australia, however, the girls were under critical scrutiny. Mr. Divett, an MP, inspected a group of orphans in Plymouth and came to an unfavourable impression of the girls. Members from the Colonial Land and Emigration Office wrote to Earl Grey to express their confidence in the scheme, stating that "though not equal to the English females whom we have been hitherto able to select, [the Irish orphans] are not ill-fitted for the rough life which the wife of an Australian labourer must be prepared to lead." 61 They go on to say that though the girls "were wanting in that orderly and tidy appearance which characterize many of the female emigrants from Great Britain" and were "generally short and not at all well-looking," they would be satisfactory to the Australian officials. ${ }^{62}$ Irish orphans

59 Duffy, 8.

60 Robins, "Irish Orphan Emigration to Australia," 377.

${ }_{61}$ Alexander C. Wood, and Frederic Rogers, Letter to the Right Honourable Earl Grey, Secretary of State, II August 1848, in Irish University Press Series of British Parliamentary Papers: Correspondence and Papers Relating to Emigration and Other Affairs in Australia, 1849-50. Vol. II (Shannon: Irish University Press, 1968-9), 35I. 62 Ibid. 
were allocated to ships separate from their English and Scottish counterparts, since it was feared that "their habits and manners make them very unacceptable companions to English emigrants." ${ }^{3}$ These colonial letters illuminate the matter in which even the scheme's greatest supporters viewed Irish emigrants as second-rate compared to their English counterparts. The orphans' lower status suggests that prejudice against the Irish extended not just to men but to women and children as well, even those whose stunted physical growth had more to do with stringent British Poor Laws than perceived deficiencies in their race.

The Earl Grey docked in October 1848 and immediately Dr. Douglass, the Surgeon-Superintendent on the ship, reported that many girls on the boat were not actually orphans. ${ }^{64}$ Douglass stated "the professed public woman, and the barefooted little country beggar have been alike sought after as fit persons to pass through the purification of the workhouse," ${ }^{\circ 5}$ calling their selection a "gross imposition."66 Earl Grey directly questioned Irish Poor Law Commissioners and concluded that some minor abuses had occurred; the selection of a group of

\footnotetext{
${ }^{63}$ Earl Grey, Letter to Governor Young, 29 August 1848, Emigration Papers (North America and Australia), 229-30, quoted in Robins, The Lost Children, 206. 64 Robins, "Irish Orphan Emigration to Australia," 379-80.

65 Douglass, Henry G., M.D, Letter to Governor Sir C. A. Fitzroy, 7 October, 1848, in Irish University Press Series of British Parliamentary Papers: Correspondence and Papers Relating to Emigration and Other Affairs in Australia, 1849-50. Vol. II (Shannon: Irish University Press, 1968-9), 418.

66 Ibid., 4 I7.
} 
rowdy girls from Ulster was considered a "great injustice ... to the colony," ${ }^{\circ}$ while several girls had emigrated under assumed names or were married and running away from their husbands. ${ }^{68}$ However, Earl Grey emphasized that "Dr. Douglass made charges of too sweeping a nature" and considered it lamentable that he had "[cast] a general and indiscriminate stigma upon a large body of young women." 69 Indeed, a report from the Orphan Immigration Committee concluded that labour hunger was such that nearly all the "Belfast girls" had been hired for high wages, while the Earl Grey's remaining girls' “orderly, obedient, and industrious conduct has earned them the commendation from all persons." ${ }^{70}$ Irish orphans were thus met with mixed response in Australia; though entrenched and sweeping prejudices emerged, a hungry labour market ensured that the orphans were well-received by local employers and single men.

Certain realities in colonial life can account for this initially ambiguous response to Irish orphans. An insatiable need for workers, hordes of single men, and

67 Francis L. S. Merewether, Report of the Orphan Immigration Committee, respecting the Female Orphans who arrived in the "Earl Grey," 6 December, 1848, in Irish University Press Series of British Parliamentary Papers: Correspondence and Papers Relating to Emigration and Other Affairs in Australia, 1849-50, Vol. II (Shannon: Irish University Press, 1968-9), 418.

68 Robins, "Irish Orphan Emigration to Australia," 380.

69 Earl Grey, Letter to Governor Sir C. A. Fitzroy, 5 October, 1849, in Irish University Press Series of British Parliamentary Papers: Correspondence and Papers Relating to Emigration and Other Affairs in Australia, 1849-50, Vol. II (Shannon: Irish University Press, 1968-9), 522.

70 Merewether, 418. 
distance from the homeland likely tempered prejudices in the colonial setting. Australia's dominant English culture meant that some clash with Irish immigrants was probably inevitable, but Malcolm Campbell notes that the combination of an interdependent rural settlement, a large Irish community (about one-fifth of the population), and undeveloped Australian nationalism "mitigated against any repeat of the intense antagonism that greeted the Irish in ... other destinations." 71 Irish famine orphans were certainly welcomed by many employers and young men. For example, despite initial caution and even antagonism, three months after the arrival of the Roman Emperor it was reported that the orphans had generally been satisfactory and many were planning to marry. ${ }^{72}$ Furthermore, colonial authorities were satisfied with the scheme and extended it from 2,500 girls to include another 2,000 orphans. $^{73}$ In some ways, therefore, the unique circumstances of colonial Australia allowed early groups of Irish orphans to enjoy unknown prosperity.

Though the initial parties of girls were quickly accepted and absorbed into the colony, antagonism quickly emerged in South Australia and New South Wales which reflected broader pre-existing prejudices. ${ }^{74}$ By mid-1849 a softened labour market and poor harvests meant that

7l Campbell, 59.

72 Robins, "Irish Orphan Emigration to Australia," $38 \mathrm{I}$.

73 Ibid., 382.

74 lbid. 
incoming Irish orphans were no longer as needed and employers could afford to be more discriminatory in their hiring. ${ }^{75}$ In 1848 and 1849 social distaste for the Irish was moderated by a practical need for their labour, whereas by late 1849 colonists considered workhouse labour "costly, inefficient and inferior in point of morals and character." ${ }^{26}$ When the Elgin, the third Irish orphan ship to enter Adelaide, docked in September 1849, "the rate of hiring was slow" and fifty-seven girls were still without work after six weeks. ${ }^{77}$ Eric Richards and Ann Herraman contend that antagonisms towards the Irish collided with economic conditions to create "a schizoid element in the official colonial mind" that left orphans caught in the middle. ${ }^{78}$ Indeed, O'Farrell notes that "Australia was for a very long time not so much a nation as an assemblage of assorted immigrants, living out the cultural and psychological baggage they had brought with them."79 As a result, prejudices against the Irish, though tempered somewhat by distance from Britain and the practical need for labour, were often transported to Australia. Complaints about Irish religion, race, and ignorance soon reared their heads in colonial

\footnotetext{
75 Eric Richards, and Ann Herraman, “'If she was to be hard up she would sooner be hard up in a strange land than where she would be known': Irish women in colonial South Australia," in Irish Women in Colonial Australia, ed. Trevor McClaughlin (St Leonards, NSW: Allen \& Unwin, 1998), 85.

76 lbid., 86.

77 Robins, "Irish Orphan Emigration to Australia," 383.

78 Richards and Herraman, 86.

79 O'Farrell, 14.
} 
Australia and suggest that the stigmas of the Irish workhouse pauper were exported around the world.

Fears of Catholicism and popery were rampant among some circles in Australia and resulted in discrimination against the colony's Irish population. Presbyterian minister J. D. Lang, a tireless crusader against Irish immigration, circulated a pamphlet in 1841 entitled The Question of Questions! with the subtitle "Is this colony to be transformed into a Province of the Popedom?"80 Lang contended that Catholics were united and would eventually outnumber Protestants, creating a dangerous political bloc. He also argued that the Irish were "the most ignorant, the most superstitious, and the very lowest in the scale of European civilisation," and their anarchic spirit meant that they might form revolutionary brotherhoods with convicts in the colony and overthrow order. $^{81}$ Others believed that the Irish' positions as servants allowed them to inform themselves of Australia's goings-on and report it to their Catholic headquarters, pretending to be poor while secretly amassing wealth. ${ }^{82}$ Lang went on to suggest that Irish women who married English and Scottish Protestants in the colony were "silently subverting and extending the Romanism of the colony." 83

80 lbid., 72.

81 lbid., 73.

82 Ibid., 8I.

83 Campbell, 58. 
In November 1849 Lang published a letter in The Times stating that the government had shown unfair preference for Irish Catholic orphans and had thus discriminated against the Church of Scotland. ${ }^{84}$ Earl Grey strongly denied the accusations, stating that "whether they be Roman Catholic or Protestant is a question which Her Majesty's government cannot permit to have any weight in deciding on the selection of Queen's subjects for a boon which is, and ought to be, open to all without distinction of religion." 85 Though colonial officials refused to discriminate against the orphans based on their religion, they nevertheless stated that colonial policy "renders it unavoidable that each colony should receive a certain proportion of Irish immigrants." ${ }^{86}$ Clearly, Catholic Irish girls would have to be tolerated, and this sense of paranoia suggests that the vision of an exclusive Anglo-Saxon, Protestant Australia remained powerful despite the Empire's broader narrative of inclusive citizenship.

Racial discrimination against the Irish continued in the colonial context as well. In 1843, Dr. Alexander Thompson stated that the Irish were as intelligent as Aborigines; "like the Aborigine, the Irish were primitive, backward, outmoded, the butt of impatience and

84 Robins, The Lost Children, 215.

85 Earl Grey, Letter to C. A. Fitzroy, I5 December 1849, Papers on Emigration to the Australia Colony, quoted in Robins, The Lost Children, 215.

86 Wood and Rogers, 35I. 
contempt." 87 Indeed, in the 1870s the English traveller Mrs Baxter judged native huts an improvement over those she had seen in Ireland. Interestingly, O'Farrell notes that the Irish in Australia were said to have a respectful relationship with the Aborigines, and often married with equality. ${ }^{88}$ Racial criticisms of the Irish were stated matter-of-factly and often not intended to be offensive. Dr. Douglass, for example, stated in his complaint about the "Belfast Girls" that "[t]hey are objects for our pity, not for our condemnation." 89 In April 1846, the Australian provided a formula for the quality of labour provided by different races: "[t]hree first rate lowland Scotch or English labourers or shepherds ... to seven west and mountain Irish or highlanders; and to ten coolies," also stating "We mean no offence in this to the Irish as a nation."90 As historian Michael de Nie has suggested, Ireland's "principal difficulty" that "it was not British"91 was a problem not just in Britain, but thousands of miles away in distant Australia as well.

The orphan girls were also criticized as ignorant and unfit for domestic labour. Many of the girls who arrived had only limited education, often a result of the failures of the British workhouse system. A local Poor Law inspector at Mohill workhouse said "I cannot say much

87 O’Farrell, 72.

88 Ibid.

89 Douglass, 418.

90 Australian, 13 April 1846, quoted in O'Farrell, 72.

91 Michael de Nie, "British Conceptions of Ireland and Irishness in the Nineteenth Century," History Compass 3 (2005): 4.

Constellations 
for their education ... several of them I think had very little, others had a tolerable amount." ${ }^{92}$ An Anglican clergyman in Plymouth stated that the girls were more suited "for milking cows and undergoing the drudgery of a farm servant's life than to perform the office of lady's maid." 93 As mentioned earlier, colonial officials suggested that Irish girls would be suited to the "rough life" of Australia, ${ }^{94}$ but placed little confidence in their domestic skills. The girls' physical stunting due to poverty was seen as evidence of their ignorance and coarseness, and in January 1850 the Argus called them "a set of ignorant creatures whose whole knowledge of household duties barely reaches to distinguishing the inside from the outside of a potato" and whose only hitherto intellectual exercise had been "trotting across a bog to fetch back a runaway pig." ${ }^{95}$ Even in labour-starved regions, complaints against the girls existed. The Goulburn Herald in March 1850 called them "utterly useless to the colony ... so stupid they are fit for nothing." 96 The workhouse system in all its shortcomings had left the orphans untrained in the domestic skills needed by "the aspiring Australian bourgeoisie." ${ }^{97}$ Furthermore, O'Farrell notes that it is possible that the

92 Fourteenth Report of Select Committee on Irish poor laws, July 1849, q. 13489 , quoted in Robins, The Lost Children, 205.

93 Reverend T. Childs and Lieutenant Carew to Emigration Commissioners, 5

August 1848, Papers on Emigration (North America and Australia), quoted in Robins, The Lost Children, 205.

94 Wood and Rogers, 35I.

95 Argus, 24 January 1850, quoted in O'Farrell, 77.

96 Goulburn Herald, 2 March 1850, quoted in Campbell, 58.

97 O’Farrell, 74. 
employers were unused to servants and ignorant in household management themselves. ${ }^{98}$ Though the Irish girls were not the only immigrant domestics to be criticized, comfortable pre-existing prejudices against the Irish led many colonists to attribute their ignorance to an inherent, sweeping deficiency in their race. The colonists were beginning to feel that "the poorhouses ... were offloading their burdens onto gullible states." 9 Altogether, the situation grew toxic for the orphans, and the scheme's days were marked.

\section{The End of the Scheme}

The vocal opposition from Lang and other colonial figures soon proved strong enough to end the Irish orphan scheme. From the scheme's inception, colonial officials had been placed on the defensive. Throughout 1848 to 1850, Australian officials reiterated to Earl Grey that "English and Scotch girls should form a due proportion of this emigration," 100 and colonial officials had to "dispel any idea ... that the interests of South Australia have been neglected in the selection of these emigrants." ${ }^{01}$ Lang wrote that he considered the emigration of Irish girls as a plot to convert Australia

\footnotetext{
$98 \mathrm{lbid}$.

99 Richards and Herraman, 90.

100 Lieutenant-Governor Sir H.E.F. Young, Letter to the Right Honourable Earl Grey, Secretary of State, 29 November 1848, in Irish University Press Series of British Parliamentary Papers: Correspondence and Papers Relating to Emigration and Other Affairs in Australia, 1849-50, Vol. II (Shannon: Irish University Press, 1968-9), 339. 101 Wood and Rogers, 352.
} 
into a "dominion of the Man of Sin."102 Interestingly, both Lang and Irish nationalists viewed the scheme as an English plot, one to sabotage the colony and the other to drain Ireland's lifeblood. In January 1850, an Adelaide newspaper, the South Australian, published an anonymous letter accusing the authorities of running, at public expense, a government brothel in the Irish orphan depot. $^{103}$ In early 1850 Melbourne's city council sent a petition to the queen asking for the discontinuation of the scheme, stating that "this particular description of immigration is totally unsuited to the general wants of the Colony." ${ }^{104}$ In spring 1850, Orphan Committees and Boards in Melbourne, Sydney, and Adelaide also voiced their disapproval of the scheme. ${ }^{105}$

Many in Australia reacted to what they felt were unjustified attacks on the morality of the orphans, and viewed the scheme as a great success. The Sydney Freeman's Journal stated "For our own part, we would prefer to leave many of these girls exposed to the dangers of starvation at home, than to have them exposed to the taunts and bad treatment which some of these have received here." 106 Residents in Yass signed a "forceful public address expressing complete satisfaction at the conduct of the women." ${ }^{107}$ The colony's Irish

102 O'Farrell, 73.

103 Robins, The Lost Children, 217.

104 Melbourne City Council Petition, 1850, quoted in Robins, The Lost Children, 216.

105 Robins, "Irish Orphan Emigration to Australia," 385.

106 Freeman's Journal (Sydney), 27 June I850, quoted in Campbell, 58.

107 Campbell, 59. 
population also responded. The Irish community in Australia was more dispersed and mobile than in North America or back home, and as a consequence vocal nationalist sentiment was considerably muted; indeed, there was no colony-wide Irish nationalist organization or newspaper in Australia. ${ }^{108}$ Nevertheless, many Irish colonists stepped forward to support the orphans, and in Melbourne, Irish Catholics sent their own petition to the queen, urging that Irish orphan emigration continue. ${ }^{109}$ Leading figures in Ireland also voiced confidence in the girls, but asked that the scheme be ended for the orphans' protection. The Earl of Mountcashel, an Irish peer, led a campaign in the House of Lords in February 1850 claiming that poor selection of surgeonsuperintendents and the sale of spirits onboard ships had led to gross misconduct and the compromise of the orphans. Thus, despite some vocalized support in Australia, the scheme was terminated. The final group of orphans was dispatched in April of 1850.110

Even among historians, the Irish orphan scheme has a deeply ambiguous history that attests to its complexity. Historian Gerard Moran states that "the female orphans schemes must be regarded as a major success" because the scheme was well-planned and supervised, and most girls managed to find work in the colony. ${ }^{111} \mathrm{He}$ also

108 O'Farrell, 15.

109 Robins, The Lost Children, 216.

110 lbid., 217-18.

III Moran, I31-32. 
notes that many girls bettered themselves abroad and wrote back to their workhouse guardians expressing gratitude for the scheme. ${ }^{112}$ Robins similarly notes that while the scheme was surrounded by controversy, most girls likely benefitted and "brought up their families in better and happier circumstances than mid-nineteenth century Ireland could offer them." ${ }^{113} \mathrm{He}$ also suggests that it is unsurprising that some young and independent girls, thrown into the uninhibited circumstances of a former penal colony, might have found themselves in trouble. ${ }^{114}$ Campbell notes that despite the vocal criticism of Lang and others, average community reaction to the orphans was likely more "muted and tolerant."115 The colonial environment had offered many girls a brighter future than could ever be achieved at home, and the need for women moderated more extreme antagonism.

In other ways, however, reaction to the scheme must be viewed more critically as an expression of discrimination against disadvantaged girls. The orphans had been placed in a vulnerable environment and often unwelcoming society, and Australia proved to be the ruin of many women. In 1851, half of Adelaide's prostitutes were Irish orphans, ${ }^{116}$ while thirty-two orphans had been brought before the magistrates for various crimes and

\footnotetext{
112 Ibid., I3I.

113 Robins, "Irish Orphan Emigration to Australia," 386.

114 Ibid.

115 Campbell, 58.

116 O'Farrell, 77.
} 
others were living in the bush in adulterous relationships or with illegitimate children. ${ }^{117}$ The scheme also tested the limits of acceptance in a formal penal colony attempting to reform itself; the colony was no longer willing to be built on the "refuse" of society. The ease with which many opponents to the scheme slipped into overused prejudices against the Irish reveals that thousands of miles had not entirely removed existing discrimination. The level of controversy surrounding the arrival of the Irish girls reveals deep, historically-rooted cracks in the rhetoric of inclusion in the British Empire. Over the course of two years, 4,175 orphan girls were sent from Irish workhouses to Australia. ${ }^{118}$ The level of Irish migration to Australia during the Famine period was indeed minute compared to that to America; "the great disaster of the Irish Famine had largely passed Australia by," 119 and when the last orphan ship sailed in April 1850, over 104,000 children remained in Irish workhouses. $^{120}$ Despite its limited scope, however, the scheme nonetheless provides insight into the complexities of Anglo-Irish relations in a colonial setting. While distance and an insatiable labour market tempered discrimination for some girls, vocal opponents to the scheme revived comfortable generalizations about the Irish as weapons against them. The girls' physical

117 Robins, "Irish Orphan Emigration to Australia," 386.

118 Ibid.

119 O'Farrell, 85.

120 Robins, "Irish Orphan Emigration to Australia," 387. 
appearance and ignorance, largely a result of poverty and terrible conditions in workhouses, were taken as racial deficiencies, while their religion was viewed as a threat. Colonial officials, meanwhile, only weakly defended the girls' character against those of English or Scottish girls. While some colonists came to the orphans' defence, the majority continued time-worn patterns of discrimination from Britain, revealing that prejudices against the Irish targeted not just men but disadvantaged girls as well. This orphan scheme is thus a valuable case study for historians seeking to explore the limits of colonial citizenship in the British Empire and to reinvigorate historiography concerning Anglo-Irish relations in the Famine era. 


\section{Bibliography}

Bean, Philip, and Joy Melville. Lost Children of the Empire: The Untold Story of Britain's Child Migrants. London: Unwin Hyman Limited, 1989.

Campbell, Malcolm. Ireland's New Worlds: Immigrants, Politics, and Society in the United States and Australia, 1815-1922. Madison, WI: University of Wisconsin Press, 2008.

De Nie, Michael. "British Conceptions of Ireland and Irishness in the Nineteenth Century." History Compass 3 (2005): 1-6.

Douglass, Henry G., M.D. Letter to Governor Sir C. A. Fitzroy, 7 October, 1848. In Irish University Press Series of British Parliamentary Papers: Correspondence and Papers Relating to Emigration and Other Affairs in Australia, 1849-50. Vol. 11, 417-418. Shannon: Irish University Press, 1968-9.

Duffy, Patrick J. Introduction to To and from Ireland:

Planned Migration Schemes c. 1600-2000. Edited by Patrick J. Duffy, 1-17. Dublin: Geography Publications, 2004.

Earl Grey. Letter to Governor Sir C. A. Fitzroy, 5 October, 1849. In Irish University Press Series of British Parliamentary Papers: Correspondence and Papers Relating to Emigration and Other Affairs in Australia, 1849-50. Vol. 11, 522-23. Shannon: Irish University Press, 1968-9.

"Irish Poor Law: past, present and future." 59pgs. London: James Ridgway, 1849. Lieutenant Carew, R.N. Letter to the Right Honourable Earl Grey, Secretary of State, 5 August 1848. In Irish University Press Series of British Parliamentary Papers: Correspondence and Papers Relating to Emigration and Other Affairs in Australia, 1849- 
50. Vol. 11, 352. Shannon: Irish University Press, 1968-9.

Lieutenant Henry, R.N., Emigration Officer. Letter to

Colonial Land and Emigration Office, 30 May, 1849.

In Irish University Press Series of British

Parliamentary Papers: Correspondence and Papers

Relating to Emigration and Other Affairs in

Australia, 1849-50. Vol. 11, 511-513. Shannon: Irish

University Press, 1968-9.

Lieutenant-Governor Sir H.E.F. Young. Letter to the Right

Honourable Earl Grey, Secretary of State, 29

November 1848 . In Irish University Press Series of

British Parliamentary Papers: Correspondence and

Papers Relating to Emigration and Other Affairs in

Australia, 1849-50. Vol. 11, 339. Shannon: Irish

University Press, 1968-9.

MacKay, Donald. Flight from Famine: The Coming of the Irish to Canada. Toronto: Dundurn Press, 2009.

Merewether, Francis L. S. Report of the Orphan

Immigration Committee, respecting the Female

Orphans who arrived in the "Earl Grey," 6

December, 1848. In Irish University Press Series of

British Parliamentary Papers: Correspondence and

Papers Relating to Emigration and Other Affairs in

Australia, 1849-50. Vol. 11, 418-420. Shannon: Irish

University Press, 1968-9.

Moran, Gerard. Sending out Ireland's Poor: Assisted emigration to North America in the nineteenth century. Dublin: Four Courts Press, 2004.

Nicholls, George. A History of the Irish Poor Law, in Connexion with the Condition of the People. 1856. Reprint, London: Augustus M. Kelley, 1967.

O'Farrell, Patrick. The Irish in Australia: 1788 to the Present. Sydney, University of New South Wales Press, 2000.

Richards, Eric and Ann Herraman. "If she was to be hard 
up she would sooner be hard up in a strange land than where she would be known': Irish women in colonial South Australia." In Irish Women in Colonial Australia, edited by Trevor McClaughlin, 82-104. St Leonards, NSW: Allen \& Unwin, 1998.

Robins, Joseph. The Lost Children: A Study of Charity Children in Ireland, 1700-1900. Dublin: Institute of Public Administration, 1980.

Robins, Joseph A. "Irish Orphan Emigration to Australia, 1848-1850." Studies: An Irish Quarterly Review, Vol. 57, No. 228 (1968): 372-387.

Robinson, Portia. The Hatch and Brood of Time: A study of the first generation of native-born white Australians, 1788-1828. Vol. 1. Oxford: Oxford University Press, 1985.

Wood, Alexander C., and Frederic Rogers. Letter to the Right Honourable Earl Grey, Secretary of State, 11 August 1848. In Irish University Press Series of British Parliamentary Papers: Correspondence and Papers Relating to Emigration and Other Affairs in Australia, 1849-50. Vol. 11, 351-352. Shannon: Irish University Press, 1968-9. 